\title{
Factors Associated with Late Detection of Breast Cancer: Application of Health Belief Model Theory
}

\author{
Wayan Wati', Ambar Mudigdo², Isna Qadrijati² \\ ${ }^{1)}$ Masters Program in Public Health, Universitas Sebelas Maret \\ ${ }^{2)}$ Faculty of Medicine, Universitas Sebelas Maret
}

\begin{abstract}
Background: Primary prevention of breast cancer is still not available, so efforts to promote early detection continue to be the major focus in fighting breast cancer. Since early detection is associated with decreased mortality, it is important to minimize delays in detection and diagnosis. The purpose of this study was to examine factors associated with late detection of breast cancer in Surakarta, Central Java, using Health Belief Model.

Subjects and Method: A cross sectional study was carried out at Dr. Moewardi Hospital, Surakarta, from October to December 2018. A sample of 200 breast cancer patients was selected by fixed disease sampling. The dependent variable was late detection of breast cancer. The independent variables were perceived susceptibility, threat, benefit, barrier, self-efficacy, family support, breast cancer detection, and family income. The data were collected by questionnaire and analyzed by a multiple logistic regression.

Results: Late detection of breast cancer decreased with perceived susceptibility $(b=-1.49 ; 95 \%$ $\mathrm{CI}=-2.55$ to $-0.42 ; \mathrm{p}=0.006$ ), perceived threat $\mathrm{b}=-1.87 ; 95 \% \mathrm{CI}=-3.05$ to $-0.69 ; \mathrm{p}=0.002$ ), perceived benefit $(\mathrm{b}=-3.27 ; 95 \% \mathrm{CI}=-4.54$ to $-2.00 ; \mathrm{p}<0.001)$, self-efficacy $(\mathrm{b}=-1.49 ; 95 \% \mathrm{CI}=-2.52$ to $-0.46 ; \mathrm{p}=0.004)$, family support $(\mathrm{b}=-1.44 ; 95 \% \mathrm{CI}=-2.49$ to $-0.39 ; \mathrm{p}=0.007$, early breast cancer detection $(b=-2.21 ; 95 \% \mathrm{CI}=-3.33$ to $-1.09 ; \mathrm{p}<0.001)$, and income $(\mathrm{b}=-1.75 ; 95 \% \mathrm{CI}=-2.92$ to $-0.59 ; \mathrm{p}=0.003)$. It increased with perceived barrier $(\mathrm{b}=1.64 ; 95 \% \mathrm{CI}=0.49$ to $2.80 ; \mathrm{p}=0.005)$.

Conclusion: Late detection of breast cancer decreases with perceived susceptibility, perceived threat, perceived benefit, self-efficacy, family support, early breast cancer detection, and income. It increases with perceived barrier.
\end{abstract}

Keywords: late detection, breast cancer, Health Belief Model

\section{Correspondence:}

Wayan Wati. Masters Program in Public Health, Universitas Sebelas Maret. Jl. Ir. Sutami 36A, Surakarta 57126, Central Java, Indonesia. Email: wayanwati99@gmail.com. Mobile: +6285842842990 .

\section{BACKGROUND}

Based on WHO data, cancer is the second largest cause of death in the world and caused 8.8 million deaths in 2015 (World Health Organization, 2018). Breast cancer is a cancer in women that can cause death (Sharma et al., 2012). According to Cancer study (2018), about one in seven women has a risk of developing breast cancer. In Indonesia, breast cancer is the leading cause of death in women, namely $21.41 \%$ of the total 92,200 deaths in 2014 (World
Health Organization, 2014). Based on the estimation of the number of breast cancer sufferers, most are found in Central Java Province, which amounted to 11,511 (Ministry of Health, 2015). In 2020 there are an estimated 1.7 million new cases of breast cancer and $70 \%$ of them die from breast cancer in developing countries (Rivera-Franco \& Leon-Rodriguez, 2018).

The incidence of breast cancer does develop in several places throughout the world, but there are gaps between developed countries and developing 
countries (Putu et al., 2016). In developed countries there is a higher incidence rate, but mortality rates are more prevalent in developing countries (Pace et al., 2015). This is due to the fact that a lot of information that cannot be accounted for is spread in the community so that patients do not treat properly and the delay comes to health care facilities (Ministry of Health, 2016).

That it is too late in seeking help and consultation is two of the main causes of morbidity and mortality in breast cancer patients in both developed and developing countries (Norsa'adah et al., 2011; Poum et al., 2014). Cases of breast cancer found in Indonesia at an advanced stage of more than $80 \%$ where one of the causes is a delay in treatment in medical services so that there is a delay in treatment of the disease and cause death (Dyanti et al., 2016).

Hospital System Data (SIRS) shows $60-70 \%$ of patients who come to the hospital at an advanced stage, so nearly half the rate of cancer incidence ends with death (Despitasari et al., 2017). The arrival of cancer patients at an advanced stage an be caused by delays that occur due to patient factors (Djatmiko et al., 2013). Stapleton et al., (2015), in his study mentioned that the delay in patients was caused by fear of coming to the hospital, lack of knowledge about symptoms of breast cancer, culture, and lack of knowledge and awareness in early detection of breast cancer. In addition, there are several factors that influence patient delay, namely husband or family support (Norsa'adah et al., 2011; Odongo et al., 2015), income (Piñeros et al., 2009; Poum et al., 2014), no symptoms of breast cancer and ignorance of symptoms of breast cancer (Norsa'adah et al., 2011).

Based on the study of Setiawan (2012), there was a significant relationship between knowledge about breast cancer and the ability to conduct BSE with a delay in the initial examination of breast cancer patients. Early detection of breast cancer aims to find breast cancer at an early stage so that treatment can be quickly given so that the survival rate increases (Rasjidi, 2011). Therefore, efforts to control delays in the initial examination of health services are an important problem so that they can reduce disease progress, increase survival rates and decrease morbidity and mortality.

SUBJECTS AND METHOD

\section{Study Design}

This study was quantitative nonexperimental with observational analytical study design with cross sectional approach. The study was conducted at Dr. Moewardi hospital Surakarta, Indonesia, in October 2018 until December 2018.

\section{Population and Samples}

The source population used in this study was breast cancer patients undergoing inpatient and outpatient care at Dr. Moewardi hospital Surakarta. The sampling was done using a fixed disease sampling technique.

\section{Study Variables}

The dependent variable was the delay in breast cancer sufferers in carrying out initial examinations to health services. Independent variables were perceptions of vulnerability, perceived threat, perceived benefits, perceived barriers, self-efficacy, family support, early detection of breast cancer, and family income.

\section{Operational Definition of Variables} Delayed visit to health care was defined as the condition of the mother of the patient who was found while taking medication to the Dr. Moewardi hospital was diagnosed as breast cancer. It is said that it is not too late if stages I and II and late if stage III and IV. 
Vulnerability perceptions defined as individual perceptions/ beliefs about the opportunity to experience a disease or health problem that has a negative impact on him so that it requires action to conduct an initial examination of health services, measured using a questionnaire.

The perception of threat defined as the encouragement of individuals to take preventive actions or cure diseases caused by perceptions of vulnerability and perception of severity, but threats that are too large actually cause fear in individuals that actually inhibits them from taking action because the individual feels powerless against the threat, measured using questionnaire.

The benefit defined as the individual's perception of the efficacy of the action in conducting an initial examination into health services to reduce the risk or seriousness of the impact of the disease, measured using a questionnaire.

Perceived barrier was defined as the individual's perception of obstacles (physical, economic, and social accessibility) to carry out the initial examination into health services, measured using a questionnaire.

Self-efficacy was defined as an individual's belief in his ability to take action, measured using a questionnaire.

Family support was defined as the statement of the study subject to the support or assistance provided by family members in dealing with breast cancer that is suffered by the subject, measured using a questionnaire.

Early detection of breast cancer was defined as an activity or action carried out by the mother in detecting breast cancer by herself to recognize early abnormalities in the breast or do her own breast examination (BSE), measured using a questionnaire.
Family income was defined as the total money in a month received by the head of the family/ father and/ or mother in the form of rupiah generated by working to meet daily family needs, calculated by making the average in the last 6 months, and measured using a questionnaire.

\section{Study Instruments}

The study instrument used for data collection was a questionnaire. The validity test was in the form of content validity and face validity. The reliability testing in this study was conducted on 20 breast cancer patients who underwent treatment at Dr. Moewardi hospital Surakarta and was done by measuring variables using the SPSS 24 statistical program.

\section{Data Analysis}

Univariate analysis was done to see the frequency distribution and percentage characteristics of study subjects. Bivariate analysis was conducted to study the relationship between the incidence of late breast cancer patients in conducting initial examinations to health services with independent variables using chi-square tests. Multivariate analysis employed a path analysis model with the Stata 13 program to determine the magnitude of the influence of determinants that influence, both those direct or indirect influences.

\section{Research Ethics}

Research ethics include informed consent, anonymity, confidentiality and ethical clearance. Ethical clearance in this study was conducted at the Medical Faculty of Universitas Sebelas Maret with protocol number 01/18/10/324 which was published on October 24, 2018.

\section{RESULTS}

\section{Sample Characteristics}

The characteristics of the study subjects were 200 study subjects. The frequency 
distribution of the characteristics of the

study subject is described in Table 1.

Table 1. The Characteristics of Study Subjects

\begin{tabular}{|c|c|c|}
\hline Variable & $\mathbf{N}$ & $\%$ \\
\hline \multicolumn{3}{|c|}{ The perception of vulnerability } \\
\hline Low & 88 & 44 \\
\hline High & 112 & 56 \\
\hline \multicolumn{3}{|c|}{ The perception of severity } \\
\hline Low & 73 & 36.5 \\
\hline High & 127 & 63.5 \\
\hline \multicolumn{3}{|c|}{ The perception of threat } \\
\hline Low & 73 & 36.5 \\
\hline High & 127 & 63.5 \\
\hline \multicolumn{3}{|c|}{ The perception of benefit } \\
\hline Low & 78 & 39 \\
\hline High & 122 & 61 \\
\hline \multicolumn{3}{|c|}{ The perception of barriers } \\
\hline Low & 130 & 65 \\
\hline High & 70 & 35 \\
\hline \multicolumn{3}{|c|}{ Self-Efficacy } \\
\hline Low & 106 & 53 \\
\hline High & 94 & 47 \\
\hline \multicolumn{3}{|c|}{ Family Support } \\
\hline Low & 81 & 40.5 \\
\hline High & 119 & 59.5 \\
\hline \multicolumn{3}{|c|}{ Early Detection of Breast Cancer } \\
\hline Yes & 114 & 43 \\
\hline No & 86 & 57 \\
\hline \multicolumn{3}{|c|}{ Family Income } \\
\hline Low & 75 & $37 \cdot 5$ \\
\hline High & 125 & 62.5 \\
\hline \multicolumn{3}{|c|}{ Education } \\
\hline Low & 95 & 47.5 \\
\hline High & 105 & 52.5 \\
\hline
\end{tabular}

\section{Bivariate Analysis}

Bivariate analysis was conducted to see the relationship of independent variables (perception of vulnerability, perceived threat, perceived benefit, perceived inhibition, self-efficacy, family support, early detection of breast cancer and respondent's income) with the dependent variable (event of late initial examination into health services) analyzed using the chisquare statistic test.
The full results of bivariate analysis can be seen in table 2. The chi-square statistical test shows that there is a relationship between perceptions of vulnerability, perception of threats, perceptions of benefits, perceptions of barriers, self-efficacy, family support, early detection of breast cancer and the income of respondents with the incidence of late initial examination into health services. 
Table 2. Bivariate Analysis

\begin{tabular}{|c|c|c|c|c|c|c|c|c|}
\hline \multirow{3}{*}{ Variables } & \multicolumn{4}{|c|}{ Breast Cancer } & \multirow{3}{*}{$\mathbf{O R}$} & \multicolumn{2}{|c|}{ CI 95\% } & \multirow{3}{*}{$\mathbf{P}$} \\
\hline & \multicolumn{2}{|c|}{ Late } & \multicolumn{2}{|c|}{ Not Late } & & \multirow{2}{*}{$\begin{array}{l}\text { Lower } \\
\text { limit }\end{array}$} & \multirow{2}{*}{$\begin{array}{l}\text { Upper } \\
\text { limit }\end{array}$} & \\
\hline & $\mathbf{N}$ & $\%$ & $\mathbf{n}$ & $\%$ & & & & \\
\hline \multicolumn{9}{|l|}{$\begin{array}{l}\text { The perception of } \\
\text { vulnerability }\end{array}$} \\
\hline Low & 66 & 75 & 22 & 25 & 0.25 & 0.13 & 0.46 & $<0.001$ \\
\hline High & 48 & 42.9 & 64 & 48.2 & & & & \\
\hline \multicolumn{9}{|c|}{ The perception of threat } \\
\hline Low & 55 & $75 \cdot 3$ & 18 & $24 \cdot 7$ & 0.28 & 0.15 & 0.53 & $<0.001$ \\
\hline High & 59 & 46.5 & 68 & 53.5 & & & & \\
\hline \multicolumn{9}{|l|}{$\begin{array}{l}\text { The perception of } \\
\text { benefit }\end{array}$} \\
\hline Low & 69 & 88.5 & 9 & 11.5 & 0.07 & 0.03 & 0.16 & $<0.001$ \\
\hline High & 45 & 36.9 & 77 & 63.1 & & & & \\
\hline \multicolumn{9}{|l|}{$\begin{array}{l}\text { The perception of } \\
\text { barriers }\end{array}$} \\
\hline Low & 58 & 44.6 & 72 & $55 \cdot 4$ & 4.96 & 2.51 & 9.80 & $<0.001$ \\
\hline High & 56 & 80 & 14 & 20 & & & & \\
\hline \multicolumn{9}{|l|}{ Self-Efficacy } \\
\hline Low & 86 & 81.1 & 20 & 18.9 & 0.09 & 0.05 & 0.19 & $<0.001$ \\
\hline High & 28 & 29.8 & 66 & 70.2 & & & & \\
\hline \multicolumn{9}{|l|}{ Family Support } \\
\hline Low & 59 & 72.8 & 22 & 27.2 & 0.32 & 0.17 & 0.58 & $<0.001$ \\
\hline High & 55 & 46.2 & 64 & 53.8 & & & & \\
\hline \multicolumn{9}{|c|}{$\begin{array}{l}\text { Early detection of breast } \\
\text { cancer }\end{array}$} \\
\hline No & 68 & 79.1 & 18 & 20.9 & 0.17 & 0.09 & 0.34 & $<0.001$ \\
\hline Yes & 46 & 40.4 & 68 & 59.6 & & & & \\
\hline \multicolumn{9}{|l|}{ Income } \\
\hline Low & 55 & 73.3 & 20 & 26.7 & 0.32 & 0.17 & 0.60 & $<0.001$ \\
\hline High & 59 & 47.2 & 66 & 52.8 & & & & \\
\hline
\end{tabular}

\section{Path Analysis}

The data processing was done using the Stata program 13. The steps of path analysis include model specifications, model identification, parameter estimation and model re-specification. The number of measured variables is 8 , the endogenous variables are 5 , and the exogenous variables are 4 . So that the value of the degree of freedom (df): 14. Therefore, it is concluded that df is over identified, which means path analysis can be done. The structural model with estimates shown in Figure 1 and the results of path analysis are shown in Table 3. Based on Figure 1, delayed breast cancer examina- tion was directly affected by perceived benefit, perceived threat, perceived barrier, breast self examination, self-efficacy and indirect can be influenced through family support, perceived susceptibility, family income, and self-efficacy.

Table 3 showed that there was a direct and negative relationship between perceived threat and delayed breast cancer detection. Mothers with strong perceived threat had logodd to experience delayed breast cancer examination 1.87 units lower than weak perceived threat $(b=-1.87 ; 95 \%$ $\mathrm{CI}=-2.85$ to $-0.90 ; \mathrm{p}<0.001)$. 
Indonesian Journal of Medicine (2019), 4(2): 105-115

https://doi.org/10.26911/theijmed.2019.04.02.04

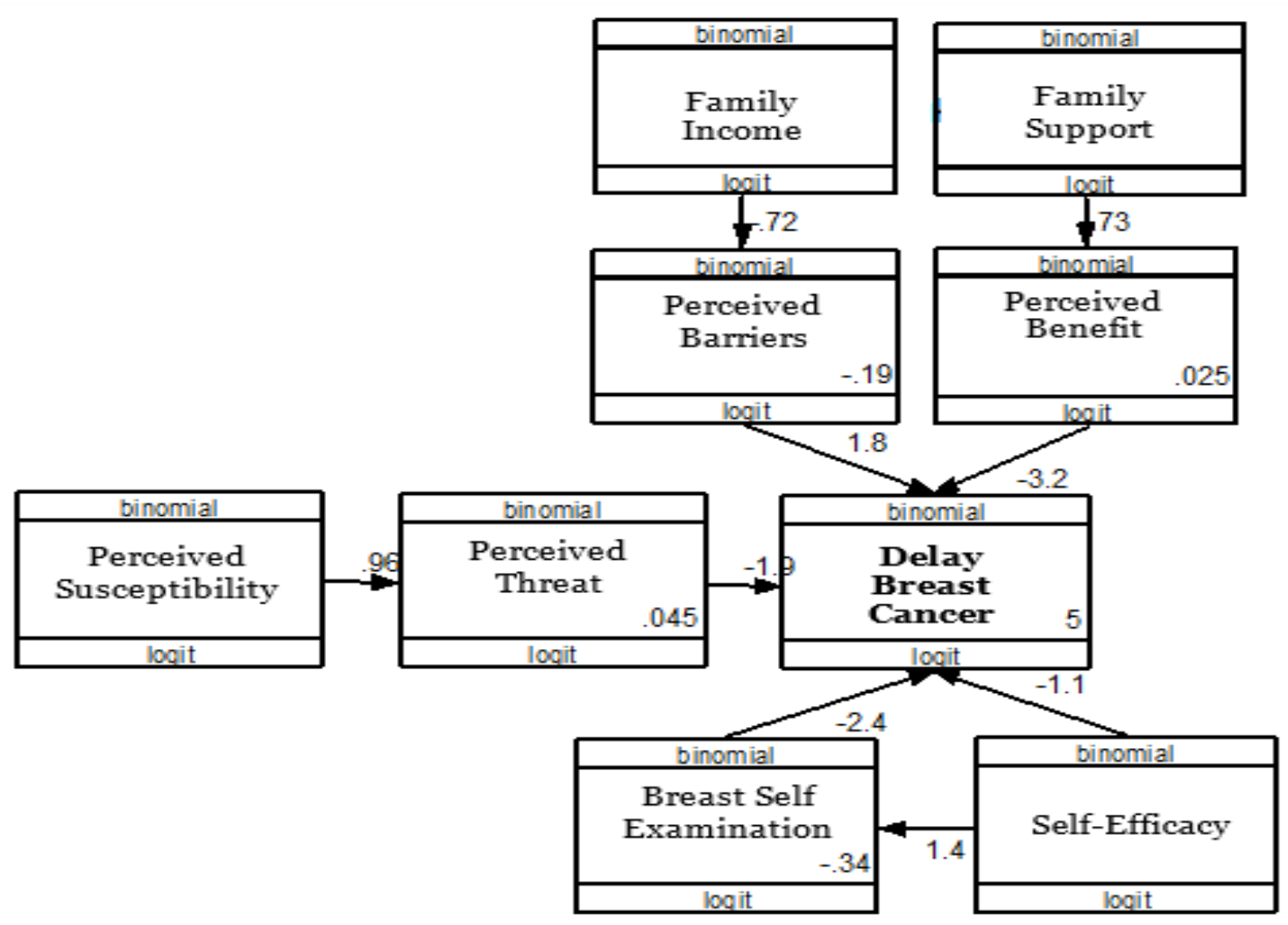

Figure 1. Structural Path Analysis Model with Estimates

Table 3. Analysis of Pathways of Biopsychosocial Determinants of Hypertension

\begin{tabular}{|c|c|c|c|c|c|c|}
\hline \multirow{2}{*}{$\begin{array}{l}\text { Dependent } \\
\text { Variable }\end{array}$} & & \multirow{2}{*}{$\begin{array}{c}\text { Independent } \\
\text { variable }\end{array}$} & \multirow[b]{2}{*}{$\mathbf{b}^{*}$} & \multicolumn{2}{|c|}{ CI (95\%) } & \multirow[b]{2}{*}{$\mathbf{P}$} \\
\hline & & & & $\begin{array}{c}\text { Lower } \\
\text { limit }\end{array}$ & $\begin{array}{c}\text { Upper } \\
\text { limit }\end{array}$ & \\
\hline \multirow{6}{*}{$\begin{array}{l}\text { Direct Effect } \\
\text { Early detection of } \\
\text { breast cancer }\end{array}$} & & & & & & \\
\hline & $\leftarrow$ & $\begin{array}{l}\text { Perceived threat } \\
\text { (strong) }\end{array}$ & -1.87 & -2.85 & -0.90 & $<0.001$ \\
\hline & $\leftarrow$ & $\begin{array}{l}\text { Perceived benefit } \\
\text { (strong) }\end{array}$ & -3.18 & $-4 \cdot 30$ & -2.06 & $<0.001$ \\
\hline & $\leftarrow$ & $\begin{array}{l}\text { Perceived barrier } \\
\text { (strong) }\end{array}$ & 1.76 & 0.75 & 2.77 & 0.001 \\
\hline & $\leftarrow$ & $\begin{array}{l}\text { Early detection of } \\
\text { breast cancer }\end{array}$ & -2.40 & -3.43 & -1.37 & $<0.001$ \\
\hline & $\leftarrow$ & Self-efficacy (strong) & -1.12 & -2.01 & -0.23 & 0.014 \\
\hline \multicolumn{7}{|l|}{ Indirect Effect } \\
\hline Perceived benefit & $\leftarrow$ & $\begin{array}{l}\text { Family support } \\
\text { (strong) }\end{array}$ & 0.73 & 0.15 & 1.31 & 0.014 \\
\hline Perceived threat & $\leftarrow$ & $\begin{array}{l}\text { Perceived } \\
\text { susceptibility (strong) }\end{array}$ & 0.96 & 0.36 & 1.55 & 0.001 \\
\hline Perceived barrier & $\leftarrow$ & Family income (high) & -0.71 & -1.31 & -0.12 & 0.018 \\
\hline $\begin{array}{l}\text { Early detection of } \\
\text { breast cancer } \\
\text { n Observation }=200 \\
\text { Log Likelihood }=-57\end{array}$ & $\leftarrow$ & Self efficacy (strong) & 1.41 & 0.80 & 2.01 & $<0.001$ \\
\hline
\end{tabular}


There was a direct and negative relationship between perceived benefit and delayed breast cancer examination. Mother with strong perceived benefit had logodd to experience delay delayed breast cancer examination 3.18 units lower than weak perceived benefit $(b=-3.18 ; 95 \% \mathrm{CI}=-4.30$ to -2.06; $\mathrm{p}<0.001$ ).

There was a direct and positive relationship between perceived barrier and delayed breast cancer examination. Mother with strong perceived barrier had logodd to experience delayed breast cancer examination 1.76 units higher than weak perceived barrier $(b=1.76 ; 95 \% \mathrm{CI}=0.75$ to $2.77 ; \mathrm{p}=$ o.001).

There was a direct and negative relationship between early detection of breast cancer and delayed breast cancer examination $(b=-2.40 ; 95 \% \mathrm{CI}=-3.43$ to -1.37 ; $\mathrm{p}<0.001)$.

There was a direct and negative relationship between self-efficacy and delayed breast cancer examination $(b=$ 1.12; $95 \% \mathrm{CI}=-2.01$ to $-0.23 ; \mathrm{p}=0.014$ ).

Perceived susceptibility was indirectly associated with delayed breast cancer examination through perceived threat $(\mathrm{b}=$ $0.73 ; 95 \% \mathrm{CI}=0.36$ to $1.55 ; \mathrm{p}=0.001$ ).

Family support was indirectly associated with delayed breast cancer examination through perceived benefit $(b=0.73$; $95 \% \mathrm{CI}=0.15$ to $1.31 ; \mathrm{p}=0.014$ ).

Family income was indirectly associated with delayed breast cancer examination through perceived barrier $(b=-0.71$; 95\% $\mathrm{CI}=-1.31$ to $-0.12 ; \mathrm{p}=0.018)$.

Self-efficacy was indirectly associated with delayed breast cancer examination through breast self examination $(b=1.41$; $95 \% \mathrm{CI}=0.80$ to $2.01 ; \mathrm{p}<0.001)$.

\begin{tabular}{l}
\hline \multicolumn{3}{c}{ DISCUSSION } \\
\hline 1. The relationship of perceived \\
threat with early detection in \\
breast cancer
\end{tabular}

The results of this study showed that there was an indirect effect between perceived susceptibility and delayed breast cancer examination through perceived threat $(b=$ $0.73 ; 95 \% \mathrm{CI}=0.36$ to $1.55 ; \mathrm{p}=0.001$ ). This study is in line with the study of Khanjani et al. (2018), which stated that perceived susceptibility was associated with delayed breast cancer examination $(\mathrm{OR}=0.87 ; 95 \%$ $\mathrm{CI}=0.78$ to 0.97$)$. Perceived susceptibility is the individual's belief about the risk of experiencing a disease or health problem (Murti, 2018). This study showed that mothers who feel vulnerable to breast cancer will immediately conduct an examination to health service.

Health Belief Model theory predicts that someone who has a perception that the risk of experiencing an illness will have a greater possibility of taking preventive measures. Conversely someone who has a low perception of vulnerability to experience an illness is less likely to experience the actions needed to prevent the occurrence of the disease (Murti, 2018).

The results of the analysis show that the perception of threat has a statistically significant relationship with the incidence of late breast cancer sufferers in carrying out the initial examination to health services. The perceived threat of signs of breast cancer refers to the extent to which a person feels that the sign of symptoms is a threat to him. This is in line with the study of Odongo et al., (2015), that someone who feels that symptoms are serious as a threat will be less likely to delay. Rahmatari (2014) stated that there was a relationship between perceived threat and early breast cancer examination behavior $(p=0.013)$. Therefore, if the perceived threat increases, 
preventive behavior also increases so that decreases delayed breast cancer examination.

\section{Relationship between perceived benefit and delayed breast cancer examination}

There was a negative relationship between perceived benefit and delayed breast cancer examination. Azwar (2003) in Desanti et al., (2010), behavior is a result of individual and environmental characteristics. A behavior can occur if the belief in the object supports the creation of a behavior. Therefore, if an individual feels vulnerable to a disease that is considered serious then it will take a preventive measure. This action depends on the benefits felt in taking these actions. Therefore, if the perceived benefits increase, preventive behavior can also increase (Rahmatari, 2014).

Family support was indirectly associated with delayed breast cancer examination through perceived benefit $(b=0.73$; $95 \% \mathrm{CI}=0.15$ to $1.31 ; \mathrm{p}=0.014$ ). Dyanti et al., (2016), stated that family support had a significant relationship with the delay in breast cancer sufferers in conducting initial examinations to health services (OR 4.35; $\mathrm{p}<0.001)$. Mothers who do not get family support will be more at risk of experiencing delays in conducting examinations (Norsa'adah et al., 2011; Odongo et al., 2015).

\section{Relationship between perceived barrier and delayed breast cancer examination}

There was a positive relationship between perceived barrier and delayed breast cancer examination. Strong perceived barrier increased the risk of delayed breast cancer examination by 1.76 units. Khanjani et al. (2018) and Prihantini et al., (2013) also stated that perceived barrier increased delayed breast cancer examination.
Family income was indirectly associated with delayed breast cancer examination through perceived barrier $(b=-0.71$; $95 \% \mathrm{CI}=-1.31$ to $-0.12 ; \mathrm{p}=0.018)$. The result of this study was in line with Khan et al. (2015), which stated that family income was significantly associated with the incidence of late breast cancer examination.

\section{Relationship between self-efficacy and delayed breast cancer exami- nation}

The result of this study showed that there was a negative relationship between selfefficacy and delayed breast cancer examinations. High self-efficacy reduced the risk of delayed breast cancer examination by 1.12 units.

Bandura's (1998) theory explained that self-efficacy is a person's belief in his ability to regulate and do something influential in his life. So that the higher the self-efficacy of the mother, then they will try to overcome the problems that occur in her through efforts to get healing.

Self-efficacy was indirectly associated with delayed breast cancer examination through self breast cancer examination $(b=$ $1.41 ; 95 \% \mathrm{CI}=0.80$ to $2.01 ; \mathrm{p}<0.001)$. High self-efficacy increased early detection of breast cancer by 1.41 units. Tavafian et al., (2009) stated that there was an association between self-efficacy and early detection of breast cancer behavior $(\mathrm{OR}=1.08,95 \% \mathrm{CI}$ : 1.02 to $1.13, p=0.003$ ). Bebis et al., (2013), also reported that there was a relationship between self-efficacy and early detection of breast cancer $(\mathrm{OR}=1.12 ; 95 \% \mathrm{CI}=1.06$ to 1.19; $\mathrm{p}<0.001$ ).

\section{The relationship of self breast examination with delayed breast cancer examination}

The results of this study showed that there was a negative relationship between breast self examination and delayed breast cancer examination. 
A study by Ghazali et al. (2013) reported that women who had never done breast self examination had higher risk 2.74 times to experience delayed breast cancer examination. Brzozowska et al. (2014) stated that there was a relationship between early detection of breast cancer and the delay in breast cancer patients seeking treatment. Setiawan (2012) reported that early detection of breast cancer reduced delay in conducting breast cancer examination.

\begin{tabular}{l}
\hline REFERENCE \\
\hline Brzozowska A, Duma D, Mazurkiewicz, T, \\
Brzozowski W, \& Mazurkiewicz M. \\
(2014). Reasons for delay in treatment \\
of breast cancer detected due to breast \\
self-examination in women from the \\
lubelskie region Przyczyny opó?nie? \\
leczenia chorych na raka piersi wykry- \\
tego w trakcie samobadania u kobiet w \\
województwie lubelskim. Ginekologia \\
Polska, 85(1):14-17. doi: 10.17772/- \\
gp/1684. \\
Bandura A (1998). Self-efficacy. In V. S.
\end{tabular}
Ramachaudran (Ed.), Encyclopedia of human behavior (Vol. 4, pp. 71-81). New York: Academic Press. (Reprinted in H. Friedman [Ed.], Encyclopedia of mental health. San Diego: Academic Press, 1998)., 4(1994):71-81. doi: 10.1002/9780470479216.corpsyo836.

Bebis H, Altunkurek SZ, Acikel C, Akar I, Altunkurek SZ (2013). Evaluation of Breast Self-Examination (BSE) Application in First and Second Degree Relatives of Patients with Breast Cancer. Asian Pacific Journal of Cancer Prevention, 14(8): 4925-4930. doi:10.7314/APJCP.2013.14.8.4925

Cancer Research (2018). Breast cancer statistics. Retrieved from https://www.cancerresearchuk.org/health-professional/cancer-statistics/statistics-by- cancer-type/breast-cancer\#headingFour

Desanti OI, Sunarsih I, Supriyati (2010). Persepsi Wanita Berisiko Kanker Payudara Tentang Pemeriksaan Payudara Sendiri Di Kota Semarang, Jawa Tengah. Berita Kedokteran Masyarakat, 26(3): 152-161.

Despitasari NL, Nofrianti D (2017). Hubungan Dukungan Keluarga dan Pemeriksaan Payudara Sendiri (SADARI) dengan Keterlambatan Pemeriksaan Kanker Payudara Pada Penderita Kanker Payudara di Poli Bedah. Journal. Um-Surabaya.Ac.Id, 2(1). Retrieved from http://journal.um-surabaya.ac.id/index.php/JKM/article/view/1110

Djatmiko A, Octovianus J, Fortunata N, Andaru I (2013). Profil Cancer Delay pada Kasus Kanker Payudara di RS Onkologi Surabaya. Indonesian Journal of Cancer, 7(2):47-52.

Ghazali SM, Othman Z, Cheong KC, Lim KH, Wan Mahiyuddin WR, Kamaluddin MA, Mustafa AN (2013). NonPractice of Breast Self Examination and Marital Status are Associated with Delayed Presentation with Breast Cancer. Asian Pacific Journal of Cancer Prevention, 14(2):1141-1145. doi:10.7314/APJCP.2013.14.2.1141.

Kemenkes (2015). Pusat data dan informasi kementrian kesehatan Republik Indonesia, InfoDatin "STOP KANKER." Ministry of Health Indonesia.

Kemenkes (2016). Oktober 2016 Bulan Peduli Kanker Payudara. InfoDATIN.

Khan MA, Hanif S, Iqbal S, Shahzad MF, Shafique S, Khan MT (2015). Presentation delay in breast cancer patients and its association with sociodemographic factors in North Pakistan. Chinese Journal of Cancer Research $=$ ChungKuo Yen Cheng Yen Chiu, 27(3):288- 
293. doi:10.3978/j.issn.10009604.2015.04.11.

Khanjani N, Rastad H, Saber M, Khandani BK, Tavakkoli L (2018). Causes of delay in seeking treatment in Iranian patients with breast cancer based on the health belief model (HBM). International Journal of Cancer Management, 11(6). doi: 10.5812/ijcm.61383

Dyanti R, Luh N (2016). Faktor-Faktor Keterlambatan Penderita Kanker Payudara Dalam Melakukan Pemeriksaan Awal Ke Pelayanan Kesehatan Info Artikel Delaying Factors In Breast Cancer Patients Taking Early Examination Into Health Services. Kemas, 11(2). doi: 10.15294/kemas.v11i2.3742.

Murti B (2018). Teori Promosi dan Perilaku Kesehatan (1st ed.). Surakarta: Bintang Fajar Offset.

Norsa'adah B, Rampal KG, Rahmah MA, Naing NN, Biswal BM (2011). Diagnosis delay of breast cancer and its associated factors in Malaysian women. BMC Cancer, 11:2-9. doi: 10.1186/1471-2407-11-141

Odongo J, Makumbi T, Kalungi S, Galukande M (2015). Patient delay factors in women presenting with breast cancer in a low income country Cancer. BMC Research Notes, 8(1):4-9. doi: 10.1186/s13104-015-1438-8.

Pace LE, Mpunga T, Hategekimana V, Dusengimana JMV, Habineza H, Bigirimana JB, Keating NL (2015). Delays in Breast Cancer Presentation and Diagnosis at Two Rural Cancer Referral Centers in Rwanda. The Oncologist, 20(7):780-788. doi: 10.1634/theoncologist.2014-0493

Piñeros M, Sánchez R, Cendales R, Perry F, Ocampo R (2009). Patient delay among Colombian women with breast cancer. Salud Pública de México, 51(5). doi: 10.1590/Soo363634200900050-
0004

Poum A, Promthet S, Duffy SW, Parkin DM (2014). Factors Associated With Delayed Diagnosis of Breast Cancer in Northeast Thailand. Journal of Epidemiology, 24(2):102-108. doi:10.2188/jea.JE20130090

Prihantini W, Yunitasari E, Pradanie R (2013). Hubungan perceived Benefit dan Perceived Barrier Dengan Stadium Kanker Payudara Berdasarkan Teori Health Belief Model Pada Pasien Yang Berkunjung Di Posa Rsud Dr. Soetomo. Journal Universitas Airlangga, 3(2):50-54. Retrieved from http://www.journal.unair.ac.id/abstract.download.php?page $=798$.

Putu N, Rossalia P, Bagus I, Wibawa T (2016). Faktor-Faktor yang Berhubungan dengan Keterlambatan Pengobatan pada Penderita Kanker Payudara di Rumah Sakit Umum Pusat (RSUP) Sanglah Denpasar. E-Journal Medika, 5(12):1-7. Retrieved from http://ojs.unud.ac.id/index.php/eum

Rahmatari A (2014). Hubungan Karakteristik, Pengetahuan, Dan Anggapan (Perceived) Wanita Usia Subur Dengan Perilaku Memeriksakan Payudara Sejak Dini (Studi di Pusat Deteksi Dini dan Diagnostik Kanker Surabaya Tahun 2014). Universitas Airlangga. Retrieved from http://repository.unair.ac.id/id/eprint/23765.

Rasjidi I (2011). Deteksi Dini dan Pencegahan Kanker pada Wanita. Jakarta: Sugeng Seto.

Rivera-Franco MM, Leon-Rodriguez E. (2018). Delays in breast cancer detection and treatment in developing countries. Breast Cancer: Basic and Clinical Research, 12. doi:10.1177/1178223417752677.

Seifeldin IA, Banerjee M, Soliman AS. (2015). presentation of breast cancer 
in Egypt, 20(5):532-537. doi: 10.1002/pon.1767.Patient-mediated.

Setiawan F (2012). Hubungan Pengetahuan dan Deteksi Dini (SADARI) dengan Keterlambatan Penderita Kanker Payudara Melakukan Pemeriksaan di RSUD Kraton Kabupaten Pekalongan. Sekolah Tinggi Ilmu Kesehatan Muhammadiyah Pekajangan.

Sharma K, Costas A, Shulman LN, Meara JG (2012). A systematic review of barriers to breast cancer care in developing countries resulting in delayed patient presentation. Journal of Onco- logy, 2012. doi:10.1155/2012/121873. Tavafian SS, Hasani L, Aghamolaei T, Zare S, Gregory D (2009). Prediction of breast self-examination in a sample of Iranian women: An application of the Health Belief Model. BMC Women's Health, 9:1-7. doi.org/10.1186/14726874-9-37

World Health Organization (2014). Cancer Country Profile: Indonesia. Cancer Country Profiles.

World Health Organization. (2018). Cancer. Retrieved from https://www.who.int/news-room/fact-sheets/detail/cancer 